\title{
Influence of Wave Action and Lithology on Sea Cliff Mass Movements in Central Algarve Coast, Portugal
}

\author{
Maria M. Bezerra ${ }^{\dagger}$, Delminda Moura ${ }^{\dagger}$, Óscar Ferreira ${ }^{\dagger}$, and Rui Taborda \\ †FCT/CIMA \\ Universidade do Algarve \\ Campus de Gambelas \\ 8005-139 Faro, Portugal \\ mbezerra@ualg.pt \\ Departamento de Geologia \\ Faculdade de Ciências da Universidade de \\ Lisboa \\ Bloco C6, Campo Grande \\ 1749-016 Lisboa, Portugal
}

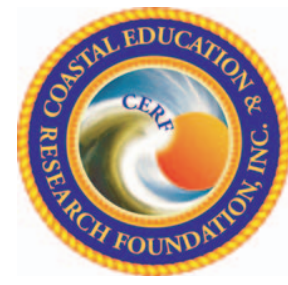

www.cerf-jcr.org

\begin{abstract}
BEZERRA, M.M.; MOURA, D.; FERREIRA, Ó., and TABORDA, R., 2011. Influence of wave action and lithology on sea cliff mass movements in Central Algarve coast, Portugal. Journal of Coastal Research, 27(6A), 162-171. West Palm Beach (Florida), ISSN 0749-0208.

The vulnerability of a rocky cliff to direct wave attack is a function of its lithological, structural, and morphological characteristics. The intensity of wave attack at the cliff foot depends on incident wave characteristics, nearshore bathymetry, beach and shore platform topography, coastline orientation, storm surges, and tidal range. The main goal of this paper is to relate the role of wave action as a geomorphic process influencing coastal cliff erosion with the control imposed by lithological and structural characteristics. For that purpose, a numerical wave propagation model (STWAVE) was used to evaluate differences in breaking wave height and energy along the study area (Galé-Olhos de Água, South Portugal) for a set of representative wave conditions and compared with existing mass movement data. As the study area presents wide longshore variation in wave exposition and breaking wave energies, five sectors were defined with contrasting wave action. When the distribution of mass movements along the coast is analyzed without considering the lithological variation, there is no relationship between the number and displaced volumes of mass movements and wave energy for each sector, with the majority of the movements and the greater volumes occurring in the least energetic sector. Therefore, lithology represents the dominant control on mass movement occurrence. However, if lithological variation is controlled by analyzing only the most common lithology in the study area (Miocene carbonate rocks), spatial variations in nearshore wave energy driven by the interaction of wave conditions with coastline orientation are found to influence mass movement occurrence.
\end{abstract}

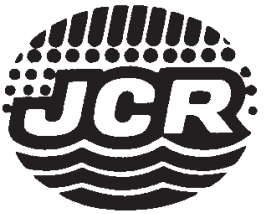

www.JCRonline.org

ADDITIONAL INDEX WORDS: Wave energy, rocky coasts, wave modeling, rock lithology, volume displaced, erosion, south Portuguese coast.

\section{INTRODUCTION}

Although a large volume of scientific work has been developed concerning shoreline evolution and coastal processes, studies on rocky coasts are scarcer than for other coastal environments. The emphasis of most modern coastal research is on beaches, salt marshes, and other economically important coastal features that change fairly rapidly and are potentially vulnerable to rising sea level (Trenhaile, 2002). The relative scarcity of research concerning rocky coasts is not in relation to their significance as one of the most common elements of the world's littoral zones (Emery and Kuhn, 1982; Griggs and Trenhaile, 1994; Trenhaile, 2002; Young et al., 2009) but may be explained by their slow responses to environmental changes when compared with other types of environment such as sandy coasts (Griggs and Trenhaile, 1994; Moura et al., 2006). Furthermore, although there have been some significant advances in the understanding of rocky coast dynamics and evolution, progress has been hindered by the low number of active researchers in this area and the inherent complexity of rocky coastal systems

DOI: 10.2112/JCOASTRES-D-11-00004.1 received 12 January 2011; accepted in revision 22 May 2011.

Published Pre-print online 26 July 2011.

(C) Coastal Education \& Research Foundation 2011
(Trenhaile, 2002), and also by the instrumental difficulties and associated costs (Marques, 1997). In the specific case of the evolutionary processes of rocky coasts and their relation to wave energy, there have been few scientific investigations.

The evolution of coastal cliffs depends on the rock mass properties (lithology, texture, and fractures), water saturation and percolation, and subaerial and marine processes (Duperret et al., 2005). Waves are the most important erosive agent along most coasts, but their effect varies with wave energy and characteristics and with the nature of the material exposed to wave attack (Summerfield, 1991; Trenhaile and Kanyaya, 2007). Rock breakdown takes place through water hammer, the generation of high shock pressures by breaking waves, and, probably most importantly in the majority of rock types, by air compression in joints and other crevices. These processes occur where air and water alternate and they therefore operate in a narrow zone above and below the fluctuating waterline (Griggs and Trenhaile, 1994; Trenhaile, 1987, 2000, 2002). Although abrasion by rock fragments, pebbles, or sand is not as closely associated with the water level, its efficacy rapidly decreases below the waterline (Komar, 1998; Trenhaile, 1987, 1997). Most mathematical models suggest that waves also exert the greatest pressures at, or slightly above, the mean water surface (Griggs and Trenhaile, 1994; Trenhaile, 2002). 
The resistance to erosion that cliffs offer is also a fundamental aspect of their evolution. Thus, cliffs' ability to withstand wave attack varies according to their resistance to erosion, as measured by their compressive, tension (tensile and penetration strengths), and cohesive properties (Bird, 2000; Duperret et al., 2005; Sunamura, 1992; Wolters and Muller, 2008).

On cliffed coasts, the shoreline retreats by temporally intermittent and spatially discontinuous slope mass movements, generally corresponding to phases of strong wave attack and heavy rain (Bird, 2000; Sunamura, 1992; Young et al., 2009). Other mass wasting processes such as abrasion, weathering, or bioerosion may play a role in cliff recession, but have negligible significance with regard to either hazard genesis or coastal cliff evolution, as they act at small spatial scales (Bird, 2000; Sunamura, 1992). Some authors have argued that local differences in cliff retreat rates are controlled primarily by the rock's mass attributes rather than by variations in the wave climate (e.g., de Lange and Moon, 2005). de Lange and Moon (2005) reported a positive relation between the discontinuities of the substratum (joints, faults, and bedding planes), platform width, and cliff recession; that is, the more discontinuities, the higher retreat rate of the cliffs and the narrower the associated shore platform. Stephenson (2008) argues that the de Lange and Moon method for assessing cliff recession rates, on the basis of the shore platform width, should not be adopted: if there is the possibility of platform inheritance from past sea levels; if evidence exists for seaward erosion of the platform (e.g., joint block removal); or if a static equilibrium model is not assumed (seaward edge of a shore platform marks the original shoreline). Wolters and Muller (2008) used finite element model predictions that pointed to an insignificant effect of cliff undercutting on cliff stability. However, in contrast, field measurements show that the deepening of such notches is responsible for the toppling failures that represent $42 \%$ of the mass movements in calcarenite rocks along the south Portuguese coast (Marques, 2008).

Quantitative studies of sea cliff evolution along the Central Algarve (southern Portugal), the study area for this investigation (Figure 1), are relatively recent. Marques (1997) assessed cliff retreat rates in Miocene calcarenites on the basis of the identification and measurement of mass movements by comparative analysis of aerial photographs (scales between $1: 15,000$ and $1: 31,500)$ covering the period 1947-1992. The maximum local retreat measured in sea cliffs cut on the Miocene rocks was $45 \mathrm{~m}$, in an arch collapse that occurred between 1974 and 1980 .

The analysis of the interactions between processes acting upon rocky cliffs in conjunction with modeling of nearshore wave propagation is a way to evaluate the main processes in coastal cliff evolution, and also the evaluation of the relative importance of wave action. The main objective of this work is to qualitatively evaluate the relative role of wave action and lithology in the retreat of coastal cliffs along the rocky coast of Central Algarve (southern Portugal) (Figure 1). For this purpose, a wave propagation model was applied to define differences in breaking wave energy along the coast and a comparison made with the distribution and extent of cliff mass movements that occurred in the period 1947-1991 (Marques, 1997).

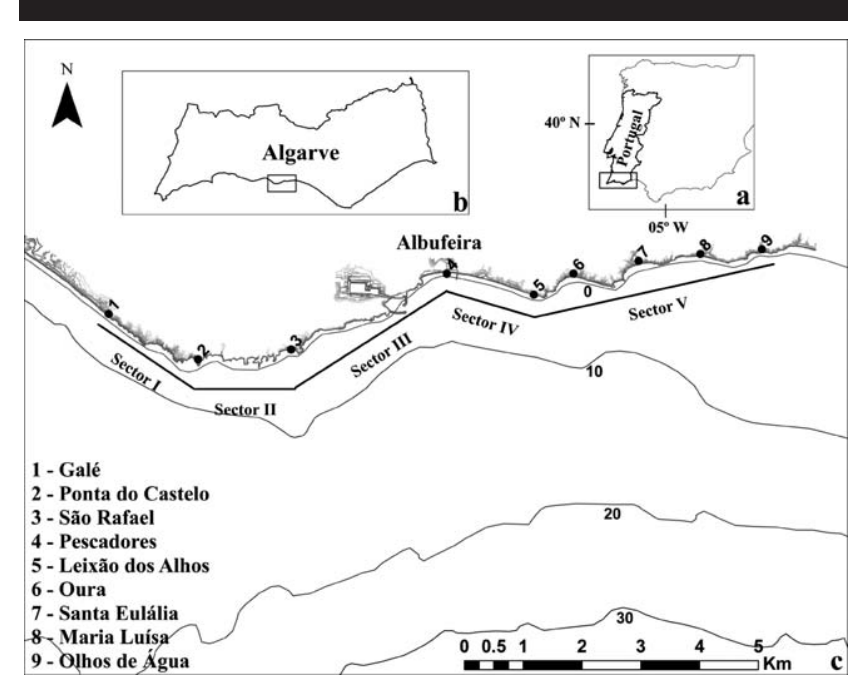

Figure 1. Location of the study area: (a) Portugal; (b) Algarve region; and (c) study coastal region between Galé and Olhos de Água, with annotation of the five sectors defined (I to V) and the places referred to in the study.

\section{STUDY AREA}

Located in the Central Algarve (South Portugal), the study area is an erosional rocky coast extending between Galé and Olhos de Água (Figure 1) with the large majority of the coastline (ca. 90\%) classified as having high or very high susceptibility to cliff erosion (Nunes et al., 2009). The coastline exposes mainly the Miocene Lagos-Portimão Carbonate Formation (Manuppella, 1992), which is mainly composed of alternating biocalcarenites, siltstones, and limestones, in meter-thick beds, trending up to $10^{\circ} \mathrm{SW}$. From W to $\mathrm{E}$ the cliffs progressively expose the upper part of the sequence eastward.

The study area presents wide alongshore variation in wave exposure, which was used to define five different sectors (Figure 1): (i) The western part of the study area, corresponding to sector I (Galé Beach to Ponta do Castelo), is oriented NWSE. The sector contains 2.51-km-long cliff sections, and the cliff heights of $c a .8 \mathrm{~m}$ make them the lowest in the study area. The exhumation of karst features carved in the nearly horizontal Miocene beds is partially responsible for an extremely crenulated coast with pocket beaches and shore platforms developed at the cliff foot at headlands. (ii) The coastline of sector II, between Ponta do Castelo and São Rafael Beach, is oriented W-E, and has 3.07-km-long cliff sections. The exposed vertical sequence is thicker than in sector I, giving rise to higher cliffs ( $c a .25 \mathrm{~m}$ ). The bedding planes dip up to $10^{\circ} \mathrm{SW}$, with the karstic forms confined to the uppermost part of the cliffs due to the hydrological barrier formed by a siltstone layer (Gabriel et al., 2008). Cliffs are affected by a dense fracture system, which favors the occurrence of marine caves. (iii) Sector III between São Rafael and Pescadores beaches is the only one that exposes not only the Miocene carbonate formation but also Cretaceous marls and Jurassic limestone (Manuppella, 1992). The shoreline in this sector is oriented SW-NE and has a cliff length and height of $2.85 \mathrm{~km}$ and $c a .40 \mathrm{~m}$, 
respectively. The near-vertical Cretaceous layers are cut by an extensive shore platform. (iv) Sector IV between Pescadores Beach and Leixão dos Alhos is oriented WNW-ESE and has a cliff length of $1.66 \mathrm{~km}$. Besides exposing the Miocene formation, cliffs $c a .30 \mathrm{~m}$ high are carved also into Plio-Pleistocene silty sands sections much weaker than the Miocene rocks in the preceding sectors. (v) From Leixão dos Alhos to the eastern end of the study area (Olhos de Água Beach), the coastline of sector $\mathrm{V}$ with 4.97-km-long cliff sections trends roughly WSW-ENE and the cliff heights can go up to $c a .40 \mathrm{~m}$. Together with sector $\mathrm{IV}$, this sector exposes the less competent rocks of the study area, and the karstic complex filled by Pliocene and Quaternary sands affects the entire cliff extent. Other attributes that distinguish sectors IV and V are more gently dipping beds from horizontal to $3^{\circ} \mathrm{SW}$. Cliffs are directly connected to shore platforms along most of sector V (Moura et al., 2006). The cliff profile in the study area is dominantly vertical although highly dependent on the position where the weakest layers occur and on the degree of karstification.

Waves from two prevailing directions act on the coast, with waves from the W-SW occurring $71 \%$ of the time and from the ESE $23 \%$ of the time. The mean offshore significant wave height for the studied area is about $1 \mathrm{~m}$ with an average peak period of 8.2 seconds (Costa, Silva, and Vitorino, 2001). According to Pires (1998), wave conditions associated with storms (waves higher than $3 \mathrm{~m}$ ) occur less than $2 \%$ of the time, and arrive mainly from the SW (232 average) and SE (128 ${ }^{\circ}$ average), occurring $64 \%$ and $32 \%$ of the time, respectively. Stormy wave conditions occur generally during maritime winter (October to March) and usually do not persist for more than 2 days (Costa, Silva, and Vitorino, 2001). Nevertheless, SW storms can persist for 2 5 days and reach maximum significant wave height greater than $6 \mathrm{~m}$. Significant heights and peak periods for stormy waves usually range between 3 and $5 \mathrm{~m}$ and 7 and 11 seconds, respectively (Costa, Silva, and Vitorino, 2001; Pires, 1998).

Return periods for extreme significant wave heights were calculated by Pires (1998) on the basis of data measured between 1986 and 1994. Results indicate that, for the same return periods, SW storms have significant wave heights approximately $2-3 \mathrm{~m}$ higher than those from the SE. The significant wave height for SE-incident waves with a 100-year return period is smaller than the significant wave height with a 5-year return period approaching from the SW.

The tidal regime in the southern coast of Algarve is semidiurnal with an average tidal range of $1.2 \mathrm{~m}$ for neap tides and $2.8 \mathrm{~m}$ for spring tides, corresponding to a mesotidal environment. However, tidal ranges of $3.3 \mathrm{~m}$ can be achieved, corresponding to a maximum high tide level of about $3.8 \mathrm{~m}$ above the hydrographical zero (chart datum, $2 \mathrm{~m}$ below mean sea level). According to data recorded by the Lagos tidal gauge between 1908 and 1987, the average rate of sea-level rise was $1.5 \mathrm{~mm} / \mathrm{y}$ (Dias and Taborda, 1992).

\section{METHODS}

\section{Wave Propagation}

A numerical wave propagation model (spectral-STate model for WAVE conditions prediction in coastal areas [STWAVE])
Table 1. Offshore wave characteristics used for wave propagation with STWAVE. $\mathrm{H}_{s}$ is significant wave height, and $\mathrm{T}_{p}$ is peak period. Data extracted from Carvalho (1994), Costa, Silva, and Vitorino (2001), Filipe, Carvalho, and Capitão (1999), and Pires (1998).

\begin{tabular}{lccllll}
\hline \hline \multirow{2}{*}{\multicolumn{1}{c}{ Condition }} & \multicolumn{2}{c}{$\mathrm{SW}\left(232^{\circ}\right)$} & & \multicolumn{2}{c}{$\mathrm{SE}\left(128^{\circ}\right)$} \\
\cline { 2 - 3 } \cline { 5 - 6 } \cline { 5 - 6 } & $H_{\mathrm{s}}(\mathrm{m})$ & $T_{\mathrm{p}}(\mathrm{s})$ & & $H_{\mathrm{s}}(\mathrm{m})$ & $T_{\mathrm{p}}(\mathrm{s})$ \\
\hline Average & 1 & 8.2 & & 1 & 8.2 \\
Storm threshold & 3 & 9 & & 3 & 9 \\
Annual storm & 4 & 9 & & 4 & 9 \\
10-y return period storm & 6.4 & 13 & & 4.6 & 9 \\
50-y return period storm & 8.1 & 13 & & 5 & 9 \\
\hline
\end{tabular}

(Smith, Sherlock, and Resio, 2001; Smith and Zundel, 2006) was used to evaluate breaking wave characteristics along the study coastline for average, storm threshold, annual storm, and 10- and 50-year return period storm conditions, for both SW $\left(232^{\circ}\right)$ and $\mathrm{SE}\left(128^{\circ}\right)$ wave regimes (Table 1$)$. These conditions represent a large range of incident waves, including dominant (average) conditions, most frequent storms (annual storms), and extreme storms (10-, 50-yr return periods). Wave incidence and attack at the cliffs was analyzed for all tested conditions. The bathymetric data used was derived from the data base of the Water Institute (2007).

\section{Significant Wave Height and Wave Energy at Breaking}

Significant wave heights at the breaking position were obtained from the simulations performed with STWAVE, for each tested condition. Significant wave height at breaking was defined as the significant wave height value immediately before the breaking limit, i.e., position with the maximum observed gradient between successive significant wave height values along wave propagation. Wave energy density $(E)$ was then computed for all obtained values, according to linear wave theory:

$$
E=\rho g H_{\mathrm{b}}^{2} / 8
$$

where $\rho$ is the seawater density $\left(\mathrm{kg} / \mathrm{m}^{3}\right), g$ is the acceleration of gravity $\left(\mathrm{m} / \mathrm{s}^{2}\right)$, and $H_{\mathrm{b}}$ is the significant breaking wave height (m).

Average significant wave height and wave energy at the breaking position were also computed for each defined sector and each tested condition. To support data integration and ease the interpretation of results, all data were then processed and represented in a geographic information system environment (ArcGIS 9.2).

\section{Mass Movements}

Using the mass movement data acquired by Marques (1997), the following variables were measured for each defined sector: (i) total volume displaced; (ii) total volume displaced per year and per cliff kilometer; (iii) volume displaced for each lithology type (Miocene carbonate rocks, M; Plio-Pleistocene sandstones, $\mathrm{PQ}$; and Cretaceous limestones and marls, CaM); (iv) volume displaced for each lithology type (M, PQ, and CaM) per year and per cliff kilometer; (v) volume displaced by movement type (rotational, S; topples, T; rock falls, F; planar, P; karst collapse, 


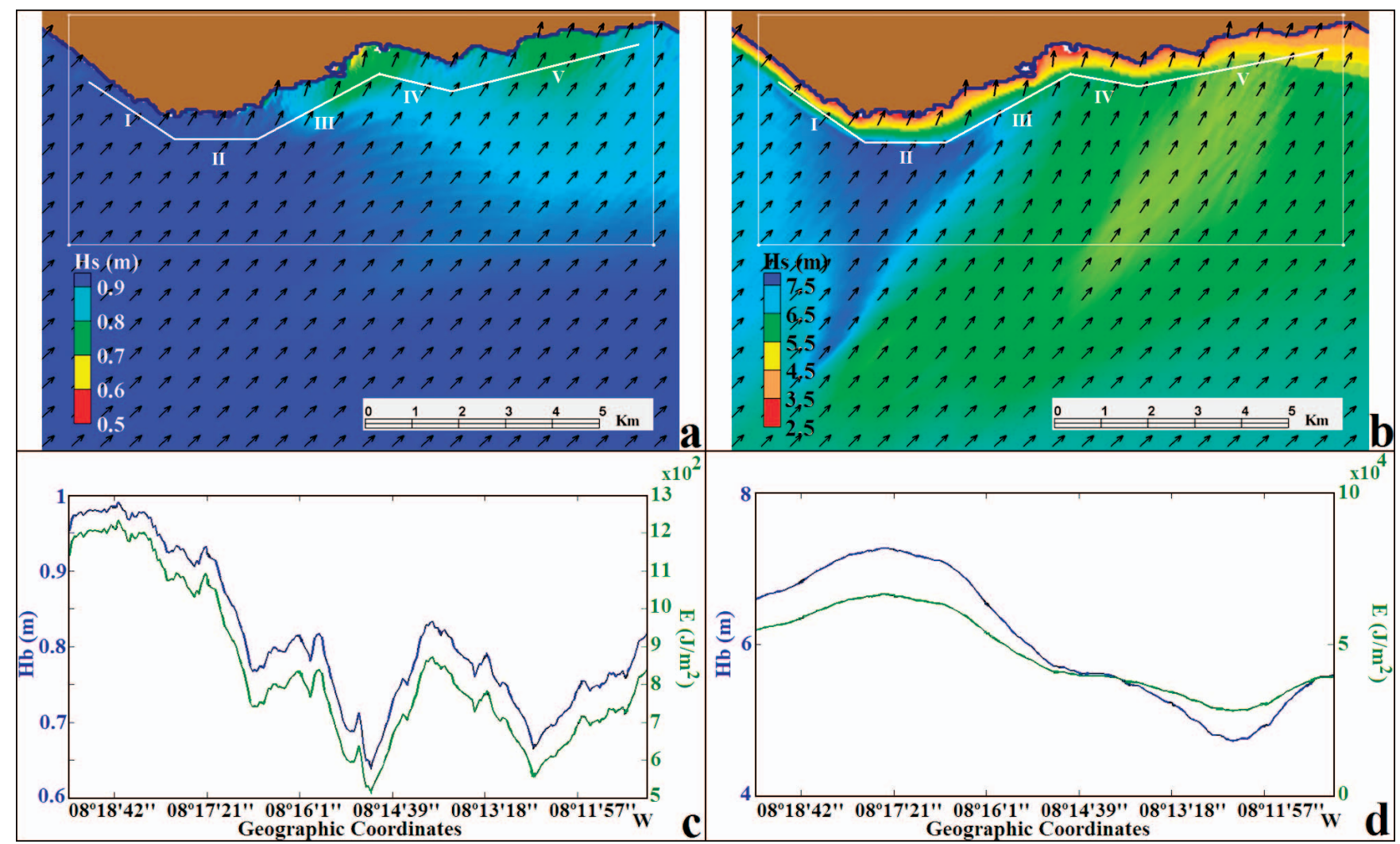

Figure 2. Nearshore wave propagation (a,b) and evolution of significant wave height $\left(H_{\mathrm{b}}\right)$ and wave energy $(E)$ at the breaking position $(\mathrm{c}, \mathrm{d})$ along the study area coastline for average (a,c) and 10-year return period storm (b,d) conditions for SW $\left(232^{\circ}\right)$ waves. The study area and the five sectors ( $\mathrm{I}$ to $\mathrm{V}$ ) are represented by the white rectangle and lines, respectively.

$\mathrm{C}$; and not determined, ND) for each lithology type (M, PQ, and $\mathrm{CaM}$ ); and (vi) number of mass movements.

\section{RESULTS}

\section{Wave Propagation}

The wave propagation results enable the knowledge of the breaking wave height $\left(H_{\mathrm{b}}\right)$ and wave energy $(E)$ distribution along the study area for the selected wave conditions. For SW waves, a similar pattern is observed for average, storm threshold, and annual storm conditions, whereas a different pattern emerges in relation to extreme storm conditions (10and 50-y return period) (Figure 2). For SE waves, a similar behavior pattern is followed by the average and storm threshold conditions, and another pattern by the annual storm, and 10- and 50-year return period storm conditions (Figure 3). Figures 2 and 3 depict only the average and 10-year return period storm conditions as these are considered representative of each behavioral group identified.

\section{Southwest Waves}

For the average SW condition (Figures $2 \mathrm{a}$ and c), differences in $H_{\mathrm{b}}$ and $E$ between headlands (sector II) and bays (Albufeira Bay or Pescadores Beach) are evident, with $E$ being concentrated and dispersed, respectively. For the 10-year return period storm for the SW condition (Figures $2 \mathrm{~b}$ and d), local differences are not so marked, although the waves in sectors I and II are higher and along Santa Eulália and Maria Luísa beaches are lower. Under these conditions, differences between headlands and bays are small and overshadowed by the differences between sectors exposed to the SW to varying degrees.

For SW conditions, the highest $H_{\mathrm{b}}$ and $E$ values (Figures 2c and d) occur in sector I for the average condition, and in sector II for the 10-year return period storm condition. The lowest values occur in sector IV (Albufeira Bay) for the average condition, and in sector V (Santa Eulália Beach) for the 10-year return period storm condition.

\section{Southeast Waves}

Differences between headlands (sector II) and bays (Albufeira Bay or Pescadores Beach) are apparent for the average SE condition (Figures $3 \mathrm{a}$ and c) as well as a clear reduction in $H_{\mathrm{b}}$ and $E$ values for sector I. For the 10 -year return period storm (Figures $3 b$ and d), local differences are not so evident but still exist for sector II, São Rafael Beach, and Leixão dos Alhos (all with higher $E$ ) and sector I, Pescadores Beach, and Oura Beach (all with lower $E$ ). Under these conditions there are no large differences between headlands and bays, unlike the case for 


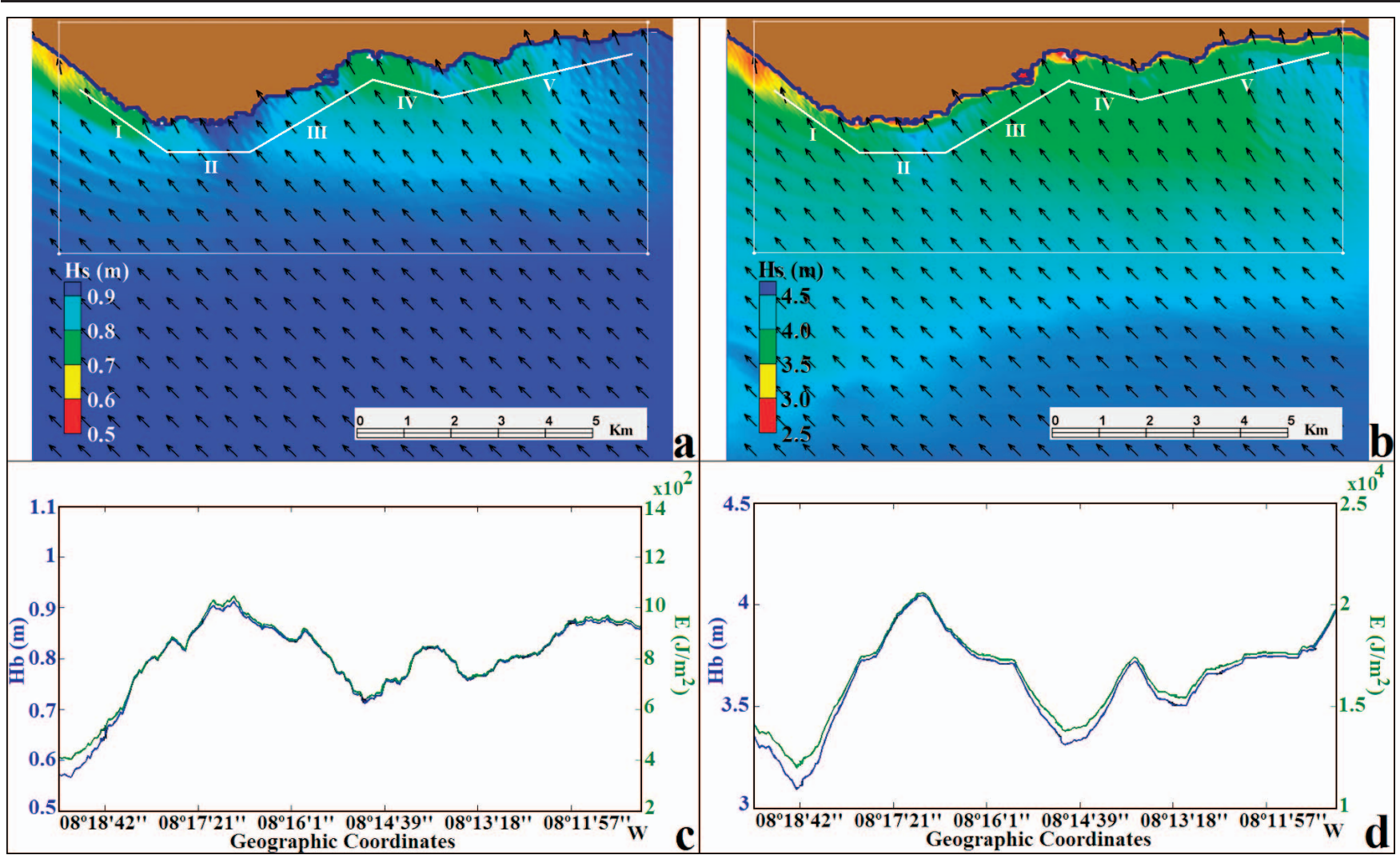

Figure 3. Nearshore wave propagation $(\mathrm{a}, \mathrm{b})$ and evolution of significant wave height $\left(H_{\mathrm{b}}\right)$ and wave energy $(E)$ at the breaking position $(\mathrm{c}, \mathrm{d})$ along the study area coastline for average (a,c) and 10-year return period storm (b,d) conditions for SE (128 ) waves. The study area and the five sectors (I to $\mathrm{V}$ ) are represented by the white rectangle and lines, respectively.

SW waves. However, differences between sectors with varying degrees of exposure to the SE are clear, particularly so regarding the significant reduction in $E$ for sector I.

For SE conditions, the highest $H_{\mathrm{b}}$ and $E$ values (Figures 3c and d) occur in sector II (westward of São Rafael Beach) for both average and 10-year return period storm conditions. The lowest values occur in sector I (Galé Beach) for both average and 10year return period storm conditions.

\section{Wave Energy}

Wave energy varies between sectors for average and 10-year return period storm conditions and according to SW and SE wave direction (Figure 4 and Table 2). For average conditions, the shoreline orientation has a crucial influence on $E$ from sector to sector depending on the wave direction. Sector I exhibits the greatest energetic contrast, yielding the largest $E$ value for SW waves and the lowest $E$ value for SE waves. The lowest $E$ value for SW waves occurs in sector $\mathrm{V}$, and the highest for SE waves occurs in sector II. SW and SE conditions act with similar wave energies in sector II. The SE waves are more energetic than the SW ones in sectors III, IV, and V (Figure 4 and Table 2).

For the 10-year return period storm condition, the SW energy is always dominant, i.e., the values of $E$ derived from the
SW storm direction are always higher than those from the SE for all sectors. The sector presenting the greatest contrast in $E$ is sector I (as for the average condition), but in this case with the second-highest $E$ value for SW waves and the lowest $E$ value for $\mathrm{SE}$ conditions. Sector II is the most energetic, yielding the highest $E$ values for both SW and SE conditions (Figure 4 and Table 2).

With respect to the distribution of wave energy across the study area, the sectors can be categorized into more and less energetic classes according to values of $E$ for all the defined conditions (Table 3). For SW waves, sector I is the most energetic for average, storm threshold, and annual storm conditions, and sector II is the most energetic for the 10- and 50 -year return period storms. The least energetic sector is generally sector $\mathrm{V}$, with the exception of the annual storm condition where it is sector IV. For the SE waves, the most energetic sector for all conditions is sector II. In contrast, sector I is the less energetic sector for all conditions except for the 50 -year return period storm condition where it is sector IV (Table 3).

\section{Mass Movements}

Marques (1997) identified 85 mass movements along the coastline between Galé Beach and Olhos de Água Beach, 


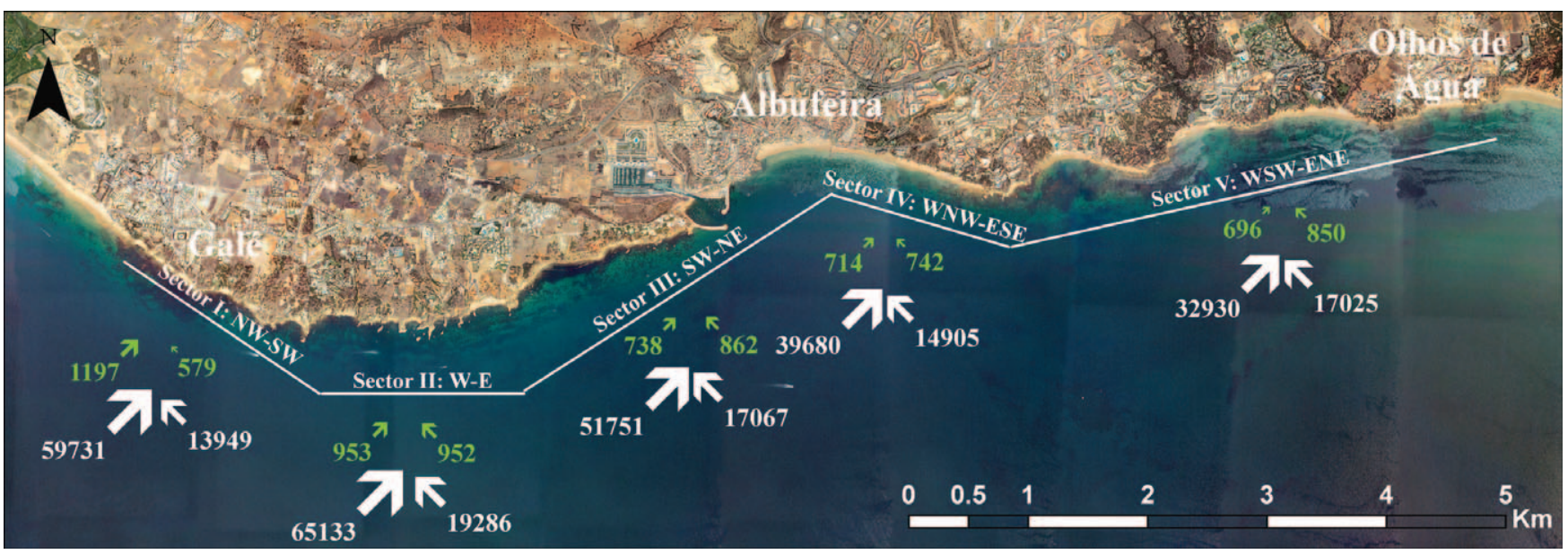

Figure 4. Variations in wave energy for each sector for average (green arrows) and 10-year return period storm (white arrows) conditions from the SW (232 ${ }^{\circ}$ ) and the SE $\left(128^{\circ}\right)$ wave climates. Arrows are proportional to the magnitude of wave energy $\left(\mathrm{J} / \mathrm{m}^{2}\right)$. Orthophotos source: Water Institute.

included in this study area. For the $15.06 \mathrm{~km}$ of coastline analyzed, the 85 mass movements occurred between 1947 and 1992 and generated a total volume displaced of $67,561 \mathrm{~m}^{3}$, or $100 \mathrm{~m}^{3}$ per year per kilometer of cliff length (Table 2).

Mass movement frequencies and spatial distributions were graphically represented with respect to the sectors (Figure 5a). The coastline sector containing the highest number of mass movements (50), and the highest and the smallest associated individual volume $\left(16,700 \mathrm{~m}^{3}\right.$-Miocene carbonate rocks and
$8 \mathrm{~m}^{3}$-Plio-Pleistocene sands and Miocene carbonate rocks, respectively) is sector $\mathrm{V}$. With respect to all 85 mass movements, the majority of the individual volumes displaced are generally in hundreds of cubic meters, with only nine mass movements having volumes in excess of $2000 \mathrm{~m}^{3}$, five of which occurred in sector $\mathrm{V}$. The number of mass movements in the other sectors is similar, but sectors II and III have higher total displacement volumes than sectors I and IV (Table 2). With respect to displaced volume per year per cliff kilometer, sector

Table 2. Measured and estimated variables with respect to the five cliff sectors. Values relative to cliff mass movements were adapted from Marques (1997). The geological structure is only related to the Miocene formations. The Plio-Quaternary is composed of sand.

\begin{tabular}{|c|c|c|c|c|c|c|}
\hline & Sector I & Sector II & Sector III & Sector IV & Sector V & Total \\
\hline Cliff coastline length (m) & 2512 & 3066 & 2849 & 1659 & 4970 & 15,056 \\
\hline Number of mass movements & 10 & 9 & 9 & 7 & 50 & 85 \\
\hline Total volume displaced $\left(\mathrm{m}^{3}\right)$ & 1217 & 10,420 & 8819 & 878 & 46,227 & 67,561 \\
\hline $\begin{array}{l}\text { Total volume displaced per year } \\
\text { per cliff kilometer }\left(\mathrm{m}^{3} \mathrm{y}^{-1} \mathrm{~km}^{-1}\right)\end{array}$ & 11 & 76 & 69 & 12 & 207 & 100 \\
\hline $\begin{array}{l}\text { Volume displaced in Miocene } \\
\text { carbonate rock }(\mathrm{M})\left(\mathrm{m}^{3}\right)\end{array}$ & 869 & 10,420 & 3227 & 878 & 8850 & 24,244 \\
\hline $\begin{array}{l}\text { Volume displaced per year per } \\
\text { cliff kilometer in } \mathrm{M}\left(\mathrm{m}^{3} \mathrm{y}^{-1} \mathrm{~km}^{-1}\right)\end{array}$ & 8 & 76 & 25 & 12 & 40 & 36 \\
\hline Orientation of the coastline & NW-SE & W-E & SW-NE & WNW-ESSE & WSW-ENE & \\
\hline Maximum cliff height (m) & 8 & 25 & 40 & 30 & 40 & \\
\hline \multicolumn{7}{|l|}{ Geological structure } \\
\hline Layers tick (m) & 1 & 1 & 2 & 2 & 2 & \\
\hline Layers inclination/orientation & $10^{\circ} \mathrm{SW}$ & $10^{\circ} \mathrm{SW}$ & Vertical & Subhorizontal & Subhorizontal & \\
\hline Layers lithology & $\begin{array}{c}\text { Biocalcarenite, } \\
\text { limestone, } \\
\text { siltstone }\end{array}$ & $\begin{array}{l}\text { Biocalcarenite, } \\
\text { limestone, } \\
\text { siltstone }\end{array}$ & Claystone & $\begin{array}{c}\text { Biocalcarenite } \\
\text { calcarenite }\end{array}$ & Biocalcarenite & \\
\hline Main system fault & NE-SW & NW-SE & - & - & NE-SW & \\
\hline \multicolumn{7}{|l|}{ Wave energy $\left(\mathrm{J} / \mathrm{m}^{2}\right)$} \\
\hline \multicolumn{7}{|l|}{$\mathrm{SW}\left(232^{\circ}\right)$} \\
\hline Average condition & 1197 & 953 & 738 & 714 & 696 & \\
\hline $10-y$ return period storm condition & 59,731 & 65,133 & 51,751 & 39,680 & 32,930 & \\
\hline \multicolumn{7}{|l|}{$\mathrm{SE}\left(128^{\circ}\right)$} \\
\hline Average condition & 579 & 952 & 862 & 742 & 850 & \\
\hline $10-y$ return period storm condition & 13,949 & 19,286 & 17,067 & 14,905 & 17,025 & \\
\hline
\end{tabular}


Table 3. Categorization of the sectors defined according to the relative incident wave energy for various wave conditions for SW and SE wave climates.

\begin{tabular}{|c|c|c|c|c|}
\hline \multirow[b]{2}{*}{ Condition } & \multicolumn{2}{|c|}{$\mathrm{SW}\left(232^{\circ}\right)$} & \multicolumn{2}{|c|}{$\mathrm{SE}\left(128^{\circ}\right)$} \\
\hline & More energetic sector & Less energetic sector & More energetic sector & Less energetic sector \\
\hline Average & I & $\mathrm{V}$ & II & I \\
\hline Storm threshold & $\mathrm{I}$ & $\mathrm{V}$ & II & I \\
\hline Annual storm & $\mathrm{I}$ & IV & II & I \\
\hline $10-\mathrm{y}$ return period storm & II & $\mathrm{V}$ & II & I \\
\hline 50 -y return period storm & II & $\mathrm{V}$ & II & IV \\
\hline
\end{tabular}

Vhas the greatest value, whereas sectors II and III have higher average annual displacement volumes than sectors I and IV (Table 2).

An analysis of the volume displaced per year per kilometer according to lithological type in each sector (Figure 6) indicates that the higher volume displaced in sector $\mathrm{V}$ corresponds primarily to Plio-Pleistocene sands $\left(37,377 \mathrm{~m}^{3}\right)$, whereas the volume displaced within carbonate rock from the Miocene (M) in the same sector is less than $1 / 4$ of this value. The most common lithological type (M) exhibits wide variation between sectors, with sector II yielding the highest value and sector I the lowest (Figure 6 and Table 2).

The most common type of mass movement with the highest volumes associated was the slump of Plio-Pleistocene sands

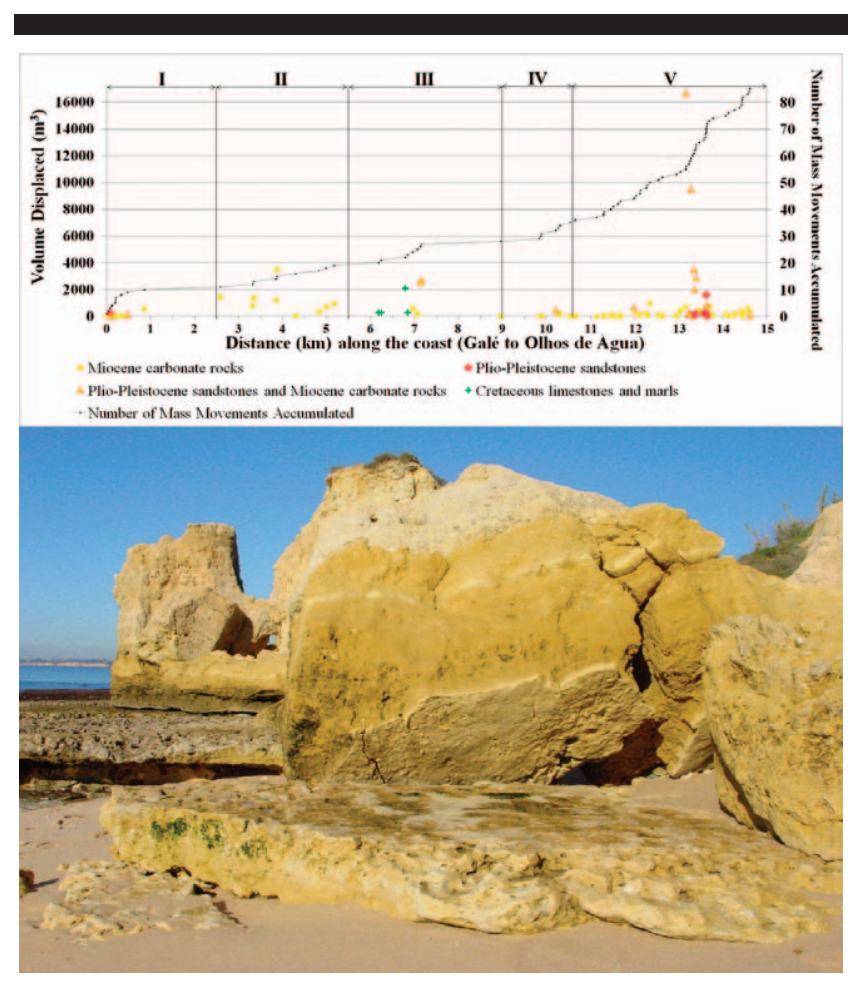

Figure 5. (a) Spatial distribution and assigned lithology of the 85 mass movements along the studied coast and the respective volumes of material displaced $\left(\mathrm{m}^{3}\right)$, from $\mathrm{W}$ to $\mathrm{E}$ through sectors I to V. (b) Photograph depicting the vertical facies variation of a cliff that exposed the Miocene carbonate formation, with a close-up of the silt layer and its lower contact after mass movement (Galé Beach, sector I). (sectors I, III, and V) and the fall and toppling of Miocene carbonate rocks (sectors II and IV, respectively).

\section{DISCUSSION}

The southern coast of the Algarve is a carbonate shore displaying a very crenulated shoreline, and therefore coastal sectors have different orientations with respect to the waves incoming from the SW and SE. These two main directions have different energetic conditions that when combined with morphological, lithological, and structural frames determine differential cliff hazard ratings (Nunes et al., 2009) and evolution due to mass movements.

\section{Wave Conditions}

The results of wave propagation simulation obtained with the STWAVE model reveal differences between the SW and SE wave conditions, and between headlands and bays. In spite of its low resolution, the bathymetry influence on the development of areas of concentration and reduction in wave energy along the coastal area investigated is evident. Differences in wave energy between SW and SE conditions for the various sectors (Figures 2 and 3) reveal the importance of shoreline orientation (Table 2) in relation to wave direction. The shoreline is in general parallel to the bathymetric contours and the dominant SW incoming waves $\left(232^{\circ}\right)$ are perpendicular to the bathymetric lines and consequently refraction effects are relatively reduced in sectors I and IV (Figures 2 and 3). However, in contrast to the exposed sector I, sector IV retains a more sheltered position protected by the headland provided by sector II (Figure 1). Accordingly, wave energy in sector I is higher than in sector IV (Figure 4 and Table 2) when the

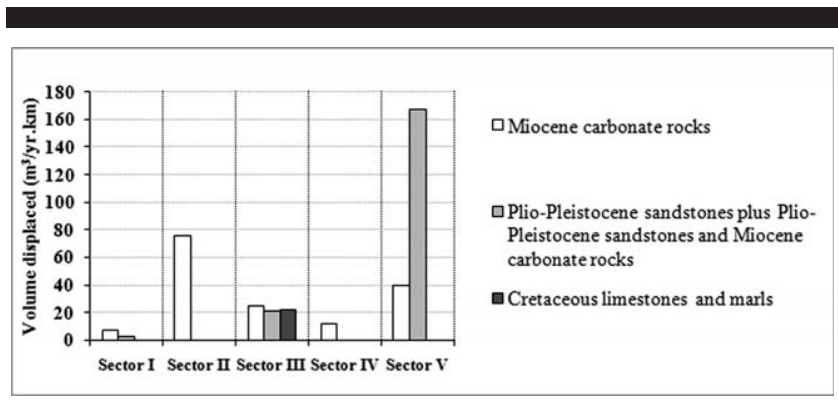

Figure 6. Volume displaced per year per cliff kilometer $\left(\mathrm{m}^{3} \mathrm{y}^{-1} \mathrm{~km}^{-1}\right)$ by lithological type for each sector. 
average SW wave condition is considered. In those two sectors (I and IV), where there is a high degree of exposure to the SW, there is also a greater attenuation of SE waves. In contrast, sectors III and V are highly exposed to the SE incident waves. The most prominent area, sector II (Figure 4 and Table 2), has a more open exposure to both the SW and SE and tends to be the most energetic.

For the average wave condition from the SW and SE (Figures 2a and $\mathrm{c}$ and $3 \mathrm{a}$ and $\mathrm{c}$ ), there is a clear differentiation between sectors according to their orientation and related wave exposure. This condition from both the SW and SE has the same peak period value (Table 1) and the difference in effect is controlled by the degree of exposure of the shore. This scenario changes in case of storm conditions. In such conditions, the longperiod waves feel the bottom farther from the shoreline and dissipate more energy offshore than the shorter-period waves. However, the more exposed sectors I and II, for the 10-year return period storm condition from the SW with a peak period $\left(T_{\mathrm{p}}\right)$ of 13 seconds (Table 1 ) have the highest energetic value (Table 2) compared with the sectors influenced by the same condition from the SE with a $T_{\mathrm{p}}$ of 9 seconds (Table 1 ). The results clearly show a morphologic control (bathymetry and coastline indentation) on exposure to waves along the coast, namely between bays (lower energy) and headlands (higher energy).

For the 10-year return period storm condition from the SW and SE (Figures $2 \mathrm{~b}$ and $\mathrm{d}$ and $3 \mathrm{~b}$ and $\mathrm{d}$ ), differences in significant wave height at the breaking position along the coastline are greater than $2 \mathrm{~m}$, implying that the different sectors are exposed to significant energetic contrasts. Wave energy associated with the SW wave regime dominates SEderived wave energy for all sectors, showing that the SW storm condition imposes higher energy levels on the study area independently of coastline orientation. In such conditions, the morphological control is not so evident given that there are no substantial differences between bays and headlands.

\section{Wave Energy and Cliff Evolution}

Coastal cliff recession evolves through intermittent and discontinuous series of mass movements, generally concentrated during phases of strong wave attack and heavy rain (Bird, 2000; Hapke and Green, 2006; Sunamura, 1992; Young et al., 2009). However, lithology, geological or bedding structure, and fracture system can be important drivers on mass movement occurrence as reported by several authors (e.g., de Lange and Moon, 2005; Hapke and Green, 2006; Trenhaile, 1987). Cliff evolution is polygenic, i.e., cliff form can be inherited, or develop by marine or aerial processes, or by a combination. However, in the Algarve study area, the spatial distribution of mass movements (Figure 5a) appears not to be primarily related to wave energy levels. For sectors I and II, the most energetic with respect to the SW wave climate (Table 3), the number of mass movements recorded is rather smaller (Figure 5a and Table 2) than for the least energetic sector (sector V) (Table 3). This may be related either to the geometric relationship between the coastline and the layer structure or the rock resistance. In fact, the cliff exposes mainly limestone and strongly cemented calcarenite with the layers dipping seaward in sectors I and II. In addition, sector V yielded the largest annual average volume of displaced material per cliff kilometer (Figure 6 and Table 2), despite its low wave energy values, pointing to lithological and structural control as the first-order factor on mass movement occurrence. Cliffs are carved into subhorizontal layers of weakly cemented calcarenite and sandstone layers displaying cross-stratification in sector V. Therefore, several caves favored by the subhorizontal structure develop at the cliff foot, leading to the collapse of the upper portions of the cliff. Additionally, the high porosity of the sandstone favors the rainwater infiltration, contributing to an acceleration of the erosion process (see Gamage et al., 2011; Wu and Tsai, 2011). Teixeira (2006) stated that $80 \%$ the mass movements at the study area occur after storm action or heavy rain as also verified for other coastal regions (e.g., Budetta, Santo, and Vivenzio, 2008).

The geomorphological context of each sector should also play an important role on the mass movements' frequency and magnitude. For instance, the relatively small amount of mass movement recorded in the more energetic sectors I and II (Figure 5a and Table 2) is probably also correlated with the extensive shore platforms at the cliff foot that contribute to the dissipation of wave energy (Duperret et al., 2005; McGlashan, Duck, and Reidi, 2008; Pierre, 2006; Walkden and Hall, 2005). Moreover, cliff height and rock mass properties have been positively correlated with cliff vulnerability to erosion (e.g., de Lange and Moon, 2005; Duperret et al., 2005). Cliffs along sector I rarely exceed $5 \mathrm{~m}$ in height, resulting in smaller volumes displaced (Figure $5 \mathrm{a}$ and Table 2 ). In addition, cliffs in sector II expose the more competent limestones of the carbonate sequence, reducing the occurrence of mass movements (Figure 5a and Table 2).

Sector III, openly exposed to the SE (Figure 3), contains only nine mass movements (Figure 5a and Table 2). Littoral cliffs in this sector are carved into Mesozoic marls and limestones dipping up to $20^{\circ} \mathrm{SW}$. These geometric relationships between bedding and the cliff face account for the lower propensity for cliff erosion in this sector. Cliffs of sector IV are carved into more detritical and softer rocks than the sectors westward, but present the smallest number of mass movements of the entire study area (Figure $5 \mathrm{a}$ and Table 2). This can be explained by the protection of sector IV by the promontory (i.e., sector II) from the dominant and vigorous SW wave climate (Figure 2).

As stated, the majority of mass movements occur in sector $\mathrm{V}$ (Figure 5a and Table 2), where cliffs expose weak Miocene carbonate sandstones, deeply incised by karstic holes filled by Plio-Pleistocene sands. Faults and joints that cut the cliffs, as well as the subhorizontal layers in this sector, conjugate to foster the cliff erosion. The reported mass movements in sector $\mathrm{V}$ displace mainly the Plio-Pleistocene sands that fossilize the Miocene karst, and provide the largest individual movement volumes observed in the study area. Although this lithomorphological frame is favorable for inducing mass movements by changes in pore water pressure and material shear stress strength during heavy rain, wave action is also important by quarrying the cliff base, which promotes cliff instability by undercutting. As observed for other coastal areas with soft cliffs (see Young et al., 2009), waves remove the mass wasted material from the cliff foot, re-exposing it to wave attack. 
Sector V has the highest displaced volume, whereas the lowest displaced volumes were reported for sectors I and IV (Figure 5a and Table 2). Sector I cliffs are the lowest (ca. $8 \mathrm{~m}$ ) and are protected by an extensive shore platform, whereas sector IV has a sheltered position (Figure 2). Sectors II and III (oriented W-E and SW-NE, respectively) contain the secondand third-highest volumes displaced after sector $\mathrm{V}$ (Figures $5 \mathrm{a}$ and 6 , Table 2). With respect to the Miocene carbonate rocks, the vast majority of mass movements are rock falls and topples, which is in agreement with the results obtained by Teixeira (2006). In addition, although some authors have argued that notching has an insignificant effect on cliff stability (e.g., Wolters and Muller, 2008), the deepening of notches is considered to be responsible for the toppling failures that represent the more frequent mass movements in the calcarenites along the south Portuguese coast (Marques, 1997, 2008; Teixeira, 2006). As sectors II and III are exposed to different wave conditions (Figures 2 and 3), the common factor contributing to the mobilization of large volumes of hard rock (rock falls and topples) is the vertical facies variation. The ca. 1-mthick impermeable silt layer constrains subaerial weathering to the cliffs' upper portion, and the contacts with the overlying porous calcarenites and the underlying limestones are planes of weakness that facilitate the collapse (Figure $5 \mathrm{~b}$ ).

There is a positive relationship between mass movement volumes displaced in Miocene carbonate rocks (Figure 6) and the incident wave energy for different sectors (Table 3), with a 0.89 correlation factor between SE storm energy (10-y return period) and the volume displaced per year per cliff kilometer. In sector II, the most energetic sector for 10- and 50-year return period storm conditions from the $\mathrm{SW}$, and for all conditions from the SE, the largest mass movement volume was displaced in Miocene carbonate rocks. In contrast, sector I, the least energetic sector for all conditions from the SE (except for the 50-y return period storm condition), showed the lowest volume displaced per year per kilometer in Miocene carbonate rocks. Therefore, although differences in lithology constitute the dominant factor explaining variation in mass movement occurrence along the study area, if only the mass movements from the Miocene carbonate formation are considered, wave energy and incidence play an important role.

Despite the flurry of process research activity in recent years, some processes have received comparatively little attention. Assessment of the potential for, and impacts of, wave quarrying and abrasion (or corrosion) on rock coast development has received very limited attention from geomorphologists. Understanding wave dynamics on platforms and the delivery of energy to the cliff toe lead to improved modeling of cliff failure and evolution (Naylor, Stephenson, and Trenhaile, 2009; Trenhaile, 2000, 2009; Young et al., 2009). Similarly, engineering models of cliff failure could inform geomorphic models of platform development (Naylor, Stephenson, and Trenhaile, 2009). Substantial benefits can be obtained by linking modeling with field studies, which can provide data for model calibration and validation (e.g., Hall et al., 2002). This study has provided such data to help understand wave action and its relationship to the evolution of rocky coasts, and in particular to estimate the relative importance of wave energy $v s$. lithological controls on cliff erosion.

\section{CONGLUSIONS}

This study used a wave propagation model to quantify breaking wave conditions and wave energy to estimate the relative role of wave action and lithology in controlling cliff erosion and evolution along the Central Algarve coast in South Portugal. The Central Algarve coastline shows clear energetic differentiation between coastal sectors, depending on the orientation of the coastline and on wave direction with respect to the two wave climate regimes operating in the area (SW and $\mathrm{SE})$. The sector that showed exposure to both wave directions proved to be the most energetic part of the coastline.

Despite variations in wave exposure and wave energy along the coast, rock lithology and structure play an important role on mass movement occurrence along the studied coastline. In sectors where the cliff substrate is composed of more detrital and friable rocks, with the palaeokarst filled by sandstones from Plio-Pleistocene, mass movements are more frequent and larger. In sectors where cliffs are composed of harder rocks, a smaller number of mass movements occur and smaller displacement volumes are involved. It takes, however, much longer to generate the internal and external conditions necessary for large mass movements in hard rocks (than in softer rocks). If only the dominant lithology type (Miocene carbonate rocks) is considered, differences in mass movement frequency are attributable to wave energy differences between sectors.

Overall, the application of hydrodynamic analysis to cliff erosion has revealed the relative importance of wave conditions and lithology to the morphological evolution of coastal cliffs in Central Algarve. A wave propagation model as used here can be utilized in other studies seeking to identify the variables that control coastal morphology and erosion, particularly where multidirectional wave climates operate and where the degree of exposure to wave conditions varies spatially.

\section{ACKNOWLEDGMENT}

This paper contributes to the research project PTDC/CTEGEX/71357/2006-MORFEA funded by the Portuguese Foundation for Sciences and Technology. The first author was supported by the project PTDC/ECM/67411/2006-BRISA (Breaking waves Interaction with Sand transport).

\section{LITERATURE CITED}

Bird, E., 2000. Coastal Geomorphology, an Introduction. Chichester, U.K.: John Wiley \& Sons, Inc., 322p.

Budetta, P.; Santo, A., Vivenzio, F., 2008. Landslide hazard mapping along the coastline of the Cilento region (Italy) by means of a GISbased parameter rating approach. Geomorphology, 94, 340-352.

Carvalho, M.M., 1994. Valores Extremos da Agitação MarítimaTemporais: Base de dados VALEXT. Clima de agitação marítima na costa portuguesa, NATO PO-WAVES Sub-projecto A. Lisboa, 25p.

Costa, M.; Silva, R., and Vitorino, J., 2001. Contribuição para o estudo do clima de agitação marítima na costa portuguesa. Lisboa: Instituto Hidrográfico, 20p.

de Lange, W.P. and Moon, V.G., 2005. Estimating long-term cliff recession rates from shore platform widths. Engineering Geology, 80, 292-301.

Dias, J.M.A. and Taborda, R., 1992. Tidal gauge data in deducing secular trends of relative sea level and crustal movements in Portugal. Journal of Coastal Research, 8(3), 655-659. 
Duperret, A.; Taibi, S.; Mortimore, R.N., and Daigneault, M., 2005. Effect of ground water and sea weathering cycles on the strength of chalk rock from unstable coastal cliffs of NW France. Engineering Geology, 78, 321-343.

Emery, K.O. and Kuhn, G.G., 1982. Sea cliffs: Their processes, profiles, and classification. Geological Society of America Bulletin, 93, 644-654.

Filipe, A.; Carvalho, M.M., and Capitão, R., 1999. Valores extremos de agitação marítima. Faro-Tratamento local dos dados existentes. Lisboa, Portugal: Laboratório Nacional de Engenharia Civil (LNEC), Relatório 179/99-NPP, 51p.

Gabriel, S.; Bezerra, M.; Moura, D.; Ferreira, Ó., and Taborda, R., 2008. Geomorfologia litoral na costa rochosa do Algarve central. Portugal, Braga: Oral communication in IV Congresso Nacional de Geomorfologia.

Gamage, K.; Screaton, E.; Bekins, B., and Aiello, I., 2011. Permeability-porosity relationships of subduction zone sediments. Marine Geology, 279, 19-36.

Griggs, G.B. and Trenhaile, A.S., 1994. Coastal cliffs and platforms. In: Carter, R.W.G. and Woodroffe, C.D. (eds). Coastal Evolution: Late Quaternary Shoreline Morphodynamics. Cambridge, United Kingdom: Cambridge University Press, pp. 425-476.

Hall, J.W.; Meadowcroft, I.C.; Lee, E.M., and van Gelder, P., 2002. Stochastic simulation of episodic soft coastal cliff recession. Coastal Engineering, 46, 159-174.

Hapke, C.J. and Green, K.R., 2006. Coastal landslide material loss rates associated with severe climatic events. Geology, 34(12), 1077-1080.

Komar, P.D., 1998. Beach Processes and Sedimentation. Upper Saddle River, New Jersey: Prentice Hall, 429p.

Manuppella, G., 1992. Notícia explicativa da Carta Geológica da Região do Algarve. Serviços Geológicos de Portugal, Lisboa, scale $1: 100,000,15 \mathrm{p}$.

Marques, F.M.S.F., 1997. As Arribas do Litoral do Algarve: Dinâmica, Processos e Mecanismos. Lisboa, Portugal: Universidade de Lisboa, doctoral thesis, $549 \mathrm{p}$.

Marques, F.M.S.F., 2008. Magnitude-frequency of sea cliff instabilities. Natural Hazards Earth System Science, 8, 1161-1171.

McGlashan, D.J.; Duck, R.W., and Reidi, C.T., 2008. Unstable boundaries on a cliffed coast: geomorphology and British laws. Journal of Coastal Research, 24(1A), 181-188.

Moura, D.; Albardeiro, L.; Veiga-Pires, C.; Boski, T., and Tigano, E., 2006. Morphological features and processes in the central Algarve rocky coast (South Portugal). Geomorphology, 81, 345-360.

Naylor, L.A.; Stephenson, W.J., and Trenhaile, A.S., 2010. Rock coast geomorphology: recent advances and future research directions. Geomorphology, 114(1-2), 3-11.

Nunes, M.; Ferreira, Ó.; Schaefer, M.; Clifton, J.; Baily, B.; Moura, D., and Loureiro, C., 2009. Hazard assessment in rock cliffs at Central Algarve (Portugal): a tool for coastal management. Ocean and Coastal Management, 52, 506-515.
Pierre, G., 2006. Processes and rate of retreat of the clay and sandstone sea cliffs of the northern Boulonnais (France). Geomorphology, 73, 64-77.

Pires, H.N.O., 1998. Project INDIA. Preliminary Report on the Wave Climate at Faro. Lisboa, Portugal: Instituto de MeteorologiaInstituto Superior Técnico, $37 \mathrm{p}$.

Smith, J.M.; Sherlock, A.R., and Resio, D.T., 2001. STWAVE: SteadyState Spectral Wave Model. ERDC/CHL 01-1. User's Manual for STWAVE, 3.0, $81 \mathrm{p}$

Smith, J.M. and Zundel, A., 2006. Full Plane STWAVE: SMS Graphical Interface. ERDC/CHL CHETN-I-71, 10p.

Stephenson, W., 2008. Discussion of de Lange WP and Moon VG 2005. Estimating long-term cliff recession rates from shore platform widths. Engeneering Geology, 80, 292-301.

Summerfield, M.A., 1991. Coastal processes and landforms. In: Global Geomorphology. London: Longman, pp. 312-342.

Sunamura, T., 1992. Geomorphology of Rocky Coasts. Chichester, U.K.: John Wiley \& Sons, Inc., 302p.

Teixeira, S.B., 2006. Slope mass movements on rocky sea-cliffs: a power-law distributed natural hazard on the Barlavento Coast, Algarve, Portugal. Continental Shelf Research, 26, 1077-1091.

Trenhaile, A.S., 1987. The Geomorphology of Rock Coasts. Oxford, U.K.: Clarendon Press, 384p.

Trenhaile, A.S., 1997. Coastal Dynamics and Landforms. Oxford, U.K.: Oxford University Press.

Trenhaile, A.S., 2000. Modeling the development of wave-cut shore platforms. Marine Geology, 166, 163-178.

Trenhaile, A.S., 2002. Rock coasts, with particular emphasis on shore platforms. Geomorphology, 48, 7-22.

Trenhaile, A.S., 2009. Modelling the erosion of cohesive clay coasts. Coastal Engineering, 56, 59-72.

Trenhaile, A.S. and Kanyaya, J.I., 2007. The role of wave erosion on sloping and horizontal shore platforms in macro- and mesotidal environments. Journal of Coastal Research, 23(2), 298-309.

Walkden, M.J.A. and Hall, J.W., 2005. A predictive mesoscale model of the erosion and profile development of soft rock shores. Coastal Engineering, 52, 535-563.

Water Institute, 2007. History: bathymetrical digital data of the littoral coast of Portugal from the National Information System for Water Resources (SNIRH). http://geo.snirh.pt/AtlasAgua/ (accessed March 2007)

Wolters, G. and Muller, G., 2008. Effect of cliff shape on internal stresses and rock slope stability. Journal of Coastal Research, 24(1), 43-50.

Wu, J-H. and Tsai, P-H., 2011. New dynamic procedure for backcalculating the shear strength parameters of large landslides. Engineering Geology, In Press. DOI: 10.1016/j.enggeo.2011.01.010.

Young, A.; Guza, R.T.; Flick, R.E.; O'Reilly, W.C., and Gutierrez, R., 2009. Rain, waves, and short-term evolution of composite seacliffs in southern California. Marine Geology, 267, 1-7.

\section{$\square$ RESUMO $\square$}

Os factores que condicionam a evolução de arribas rochosas são variados, incluindo processos continentais, marinhos e factores intrínsecos ao próprio substrato rochoso. Por exemplo, a vulnerabilidade das rochas ao ataque directo das ondas é igualmente função das suas características litológicas e estruturais. Por sua vez, a intensidade do ataque às arribas rochosas pelas ondas depende de características das ondas, da batimetria, da topografia das praias e plataformas de abrasão adjacentes, da orientação da linha de costa, da existência de sobreelevação do nível do mar e da amplitude das marés.

O sector costeiro de arribas rochosas do Algarve central (Galé a Olhos de Água), proposto para estudo, expõe principalmente a Formação Carbonatada de LagosPortimão, do Miocénico. Constitui excepção o sector entre as praias de S. Rafael e da Baleeira, onde as arribas litorais expõem margas do Cretácico e calcários do Jurássico. O principal objectivo deste trabalho é definir o papel da acção das ondas, como um processo geomórfico, na erosão de arribas costeiras e comparar com o controlo imposto pelas características litológicas e estruturais das rochas. Para tal, foi utilizado um programa de modelação da agitação marítima (STWAVE) para determinar diferenças nas características das ondas na rebentação, ao longo do troço costeiro em estudo. A altura e energia das ondas na rebentação foram obtidas para cada condição testada e foram comparadas com os dados de movimentos de massa existentes. Uma vez que a linha de costa da área de estudo mostra uma forte variação longilitoral em relação à sua exposição às ondas, foram definidos cinco sectores com diferentes orientações. Dada a orientação diferenciada dos troços e a variabilidade longilitoral nas geoformas que os constituem, foi possível analisar a frequência de ocorrência de uma dada geoforma ao longo de troços com igual litologia mas com diferente orientação à ondulação dominante.

Os resultados deste trabalho apontam para uma clara diferenciação energética entre troços costeiros, em função da sua orientação e do rumo de agitação (ex. SW versus SE). Quando se faz uma análise dos movimentos de massa sem considerar as variações litológicas, não se observa nenhuma relação entre o número e volume deslocado dos movimentos de massa e a energia das ondas para cada sector, com a maioria dos movimentos e os maiores volumes a ocorrerem no sector menos energético. Assim, a litologia representa o factor de controlo dominante na ocorrência de movimentos de massa. Contudo, ao analisar apenas o tipo litológico mais comum na área de estudo (rochas carbonatadas do Miocénico), verifica-se que as variações longilitorais de energia das ondas derivadas da interacção das condições de onda com a orientação da linha de costa são determinantes na ocorrência de movimentos de massa nesta litologia. 
Copyright of Journal of Coastal Research is the property of Allen Press Publishing Services Inc. and its content may not be copied or emailed to multiple sites or posted to a listserv without the copyright holder's express written permission. However, users may print, download, or email articles for individual use. 